\title{
POLA RUANG EKONOMI DI KAWASAN PINGGIRAN PERKOTAAN
}

\author{
Eppy Yuliani ${ }^{1}$ \\ Mila Karmila ${ }^{2}$ \\ M.Agung Ridlo ${ }^{3}$ \\ Prodi Perencanaan Wilayah dan Kota, Fakultas Teknik .Universitas Islam Sultan Agung ${ }^{1,2,3}$ \\ Penulis Koresponding email : eppy@unissula.ac.id
}

\begin{abstract}
The development of the center of the city of Semarang is very rapid, leading to the outskirts. The outskirts, which were originally used as agricultural areas, have now been converted into built-up areas, settlements, trade and services. This research was conducted in Tembalang Village, which is an educational area, new settlements accompanied by the growth of economic activity. The purpose of this study is to find patterns of economic space in suburban urban areas. Methodology Descriptive analysis research using a qualitative and rationalistic deductive approach that focuses on the environmental approach (behavior approach) and the spatial economic approach. From the results of the analysis, it is concluded that Tembalang Village has an Economic Spatial Pattern that develops along the main road. Economic activities that follow this main road route form a network pattern. This pattern of economic space is also still visible in the surrounding area. The pattern of economic space that develops on the main road corridor has a high selling value of land. Every year there is an increase in land prices, both according to NJOP, land rental prices and land selling prices. Keywords: pattern, space, economy, activity, suburbs, urban.
\end{abstract}

\begin{abstract}
ABSTRAK
Perkembangan pusat Kota Semarang yang sangat pesat, mengarah pada kawasan pinggiran. Kawasan pinggiran yang awalnya sebagai fungsi kawasan pertanian, banyak beralih fungsi menjadi kawasan terbangun, pemrmukiman, perdagangan dan jasa. Penelitian ini dilakukan di Kelurahan Tembalang, yang merupakan kawasan pendidikan, permukiman baru disertai dengan pertumbuhan aktivitas ekonomi. Tujuan penelitian ini menemukan pola ruang ekonomi pada kawasan pinggiran perkotaan. Metodologi Penelitian analisis deskriptif dengan menggunakan pendekatan deduktif Kualitatif Rasionalistik yang berfokus pada pendekatan lingkungan (behaviour approach) dan pendekatan ekonomi keruangan (spatial economic approach). Dari hasil analisis disimpulkan Kelurahan Tembalang memiliki Pola Ruang Ekonomi yang berkembang di sepanjang jalan utama. Kegiatan perekonomian yang mengikuti jalur jalan utama ini mementuk pola jaringan. Pola ruang ekonomi ini juga masih terlihat pada kawasan sekitarnya. Pola ruang ekonomi yang berkembang pada koridor jalan utama, memiliki nilai jual lahan yang tinggi. Semakin tahun mengalami kenaikan harga lahan baik menurut NJOP, harga sewa lahan maupun harga jual lahan.

Kata kunci : pola,ruang, ekonomi, aktivitas, pinggiran, perkotaan.
\end{abstract}




\section{PENDAHULUAN}

Kebijakan Pemerintah Kota Semarang tahun 1990 merelokasi aktivitas Perguruan Tinggi yang berada di pusat kota pindah ke kawasan pinggiran, khususnya kawasan Tembalang hingga saat ini perekmbangannya sangat pesat. Sebelumnya, kawasan ini berfungsi sebagai kawasan pertanian Kota Semarang. Masyarakatnya sebagian besar bermatapencaharian sebagai petani, buruh pabrik, tukang bangunan. Kondisi saat ini, setelah adanya aktivitas perguruan tinggi, banyak masyarakat pendatang sehingga berpeluang munculnya aktivitas ekonomi pada masyarakat dan pembangunan permukiman baru untuk memfasilitasi kebutuhan masyarakat.

Terbentuknya aktivitas ekonomi (commercial activity) merupakan bagian dari perkembangan aktivitas masyarakat kawasan pinggiran perkotaan, dimana aktivitas ini memberikan pengaruh yang cukup besar dengan timbulnya fasilitas ekonomi baik yang disediakan oleh pemerintah kota ataupun swadaya masyarakat.

Tingginya aktivitas ekonomi masyarakat di kawasan pinggiran perkotaan berakibat meningkatnya harga lahan . Yang terjadi saat ini di Kawasan Pinggiran Perkotaan khusnya di Tembalang di kota Semarang, harga lahan meningkat pesat kareae banyaknya permintaan kebutuhan perumahan dan aktivitas ekonomi.

Penelitian Pola Ruang Ekonomi di Kawasan Pinggiran Perkotaan ini penting dilakukan sebagai kontribusi arahan pengendalian ruang pada Rencana Detail Tata ruang Kota khsunya BWK Tembalang.

Tujuan menemukan pola ruang ekonomi pada kawasan pinggiran perkotaan. Menganalisis kondisi fungsi ruang eksisting lokasi studi. Menemukan pola aktivitas ekonomi masyarakat. Menyusun peta ruang ekonomi kawasan.

Studi ini sangat penting artinya dalam upaya menangani permasalahan pemanfaatan ruang di kawasan pinggiran perkotaan. Urgensi penelitian ini juga dikarenakan pengembangan kawasan pinggiran perkotaan yang sangat pesat dapat memberikan kontribusi ekonomi wilayah. Tingginya aktivitas ekonomi, berpeluang dalam alih fungsi ruang. Dan mengetahui sebaran ruang ekonomi di kawasan pinggiran perkotaan.

\section{LITERATUR REVIEW}

Pola Ruang, menurut Yunus (2005) dimaknai sebagai ruang (space) merujuk pada makna keluasan yang dapat diartikan secara absolut dan relatif. Arti absolut ruang adalah ruang yang bersifat riil, maujud dan kasad mata yang dapat diamati secara langsung maupun tidak langsung yang terdapat di permukaan bumi. Sebagai contoh ruang permukiman, 
persawahan, daerah yang mengalami kerusakan, bencana . Sedangkan arti relatif suatu ruang atau ruang relatif merupakan konsep yang diciptakan oleh manusia yang bersifat persepsual. Sebagai contoh istilah ruang ekonomi (economic space), ruang publik (public space), ruang sosial (social space). Dalam hal ini ruang dapat difahami sebagai fungsi tematik suatu wilayah di permukaan bumi, dengan mengakomodasikan bentuk kegiatan dalam memenuhi kebutuhan masyarakat.

Sedangkan pengertian pola ruang, berasal dari dua kata pola (pattern) dan ruang (space). Pola dapat diartikan secara komprehenseif sebagai suatu ke khasan sebaran obyek yang dibatasi oleh areal-areal di permukaan bumi. Pola ruang mengabstraksikan kenampakan suatu area yang menjadi bentuk tertentu seperti titik-titik, garis ataupun bidang. Pola ruang merupakan salah satu unsur penting dalam rencana tata ruang yang menjelaskan mengenai pembagian wilayah berdasarkan fungsinya. Secara umum, pola ruang dibagi menjadi dua yaitu kawasan lindung dan budidaya. Pola ruang menggambarkan fungsi dan peruntukkan dalam suatu ruang (Arozan, 2018).

Perkembangan daerah pinggiran kota ditandai dengan tumbuhnya kawasan permukiman baru dan semakin padatnya permukiman lama. Pertautan antara komunitas baru dan penduduk lokal tersebut menimbulkan pertanyaan menarik, berkaitan dengan dampak pembangunan permukiman baru di pinggiran kota terhadap peningkatan perekonomian lokal. Dalam konteks inilah peran wanita didudukkan sebagai pelaku kunci yang dapat mendorong perkembangan wilayah sekitar, terutama melalui menjalarnya trickle down effect, yang ditimbulkan permukiman baru tersebut (Ariyani, 2010).

Sedangkan menurut Yunus, (2008) daerah pinggiran kota yang juga dikenal dengan "urban fringe” atau "peri urban” merupakan kawasan yang perlu perhatian. Karena kawasan ini mempunyai peranan penting terhadap kehidupan penduduk, dimana terjadi transisi perubahan aktivitas perdesaan menjadi perkotaan. Kondisi ini terjadi karena kawasan pinggiran yang terletak antar a dua wilayah yang memiliki karakter perkotaan disisi lain memiliki kenampakan perdesaan. Kawasan pinggiran yang berbatasan langsung dengan perdesaan didalamnya masih banyak penduduk desa yang menggantungkan penghidupannya pada sektor pertanian. Kawasan ini merupakan sasaran perkembangan fisikal baru dari kota. Konflik antara mempertahankan lahan pertanian sebagai penghidupan masyarakat perdesaan dan kepentingan perkembangan kota merupakan bentuk konflik pemanfaatan lahan yang paling menonjol. Dalam konsepsi wilayah peri Urban dijelaskan bahwa istilah peri merupakan kata sifat yang berarti pinggiran, sementara urban juga berarti sifat kekotaan. Oleh karen itu kawasan pinggiran perkotaan identik dengan wilayah peri urban, yang sebenarnya merupakan 
Jurnal Planologi Vol. 18 No. 2, Oktober 2021 Available : http://jurnal.unissula.ac.id/index.php/psa

wilayah yang berada antara wilayah perkotaan dan wilayah perdesaan. Dari segi fisik morfologi diindikasikan oleh bentuk pemanfaatan lahan non agraris versus pengginaan lahan agraris, dari sisi perkotaan wilayah didominasi dengan pemanfaatan lahan non agraris sedangkan dari sisi perdesaan bentuk pemanfaatan lahan agraris. Pada kawasan pinggiran terdapat pencampuran bentuk pemanfaatan lahan perkotaan dan bentuk pemanfaatan lahan non agraris mengisyaratkan adanya penjalaran lahan perkotaan ke arah luar dan makin dekat jarak lahan kekotaan terbangun utama, maka makin intensif perkembangan kenampakan fisikal kekotaannya, sebaliknya semakin menjauh akan semakin berkurang intensitas perkembangan kenampakan fisikal kekotaannya.

Menurut Zahnd (2003), secara teoritis ada tiga cara dalam perkembangan dasar suatu kota. Teknis cara perkembangan dasar di dalam kota, yaitu perkembangan horizontal, perkembangan vertikal, dan perkembangan interstisial. Selain perkembangan kota, dikenal juga istilah perembetan kota. Perembetan kenampakan fisik kota merupakan salah satu bentuk dari perkembangan sebuah kota Kawasan-kawasan yang merupakan hinterland sebuah kota perlahan-lahan berubah memiliki sifat kekotaan. Terdapat tiga buah bentuk perembetan kenampakan fisik kota, yaitu perembetan konsentris, perembetan memanjang, dan perembetan meloncat.

Yuliani, 2016 menyatakan bahwa wilayah pinggiran yang diistilahkan dengan rural-urban fringer adalah wilayah peralihan mengenai pemanfaatan lahan, karakter sosial dan demografis dan wilayahnya terletak antara :

a) Lahan kekotaan yang kompak terbangun menyatu dengan pusat kota dan

b) Lahan perdesaan yang hampir tidak ditemukan bentuk lahan kekotaan dan permukiman kekotaan.

Kawasan pinggiran perkotaan merupakan wilayah yang dinamis. Penyebab utamnya adalah tingginya kekuatan penarik (magnetic forces/pull forces/attarcting forces) bagian ini baik bagi penduduk maupun fungsi perkotaan. Secara umum dinyatakan bahwa makin dekat dengan lahan terbangun makin kuat daya tarik bagian ini dan makin jauh makin lemah daya tariknya. Fakta empiris menunjukkan bahwa pendatang-pendatang di kawasan pinggiran tidak berasal dari bagian yang lebih jauh dari lahan kota yang terbangun saja , namun banyak pula yang datang dari bagian dalam kota. Apabila logika dasar yang digunakanuntuk membahas perpindahan penduduk maupun fungsinya adalah kedekatan lahan terhadap lahan terbangun dan konsentrasi fasilitas. Namun penalaran ini tidak diterima, kenyataanya masih banyak penduduk yang meninggalkan pusat kota berpindah ke kawasan pinggiran. Hal ini memunculkan penyebab lain yang tidak terkait dengan konsentrasi dan pusat fasilitas. 
Jurnal Planologi Vol. 18 No. 2, Oktober 2021

Available : http://jurnal.unissula.ac.id/index.php/psa

Sebab-sebab tertentu tersebut sebenarnya menjadi kekuatan-kekuatan penentu penyebab terjadinya mobilisasi tempat tinggal (residential mobility) dan mobilitas fungsi (functional mobility). Pengertian fungsional disini diartikan sebagai kegiatan atau aktivitas. Setiap analisis pergerakan spasial horisontal (spatial horizontal movement) jelas tidak hanya menekankan pada daerah tujuan, namun juga jharus memperhatikan daerah asal . dalam wilayah pinggiran perkotaan dikenal 3 kekuatan spasial yaitu : kekuatan spasial sentrifugal; kekuatan sebtripetal dan kekuatan lateral (Zahn, 2003)

\section{METOLOLOGI}

Pendekatan Metodologi Penelitian, Secara umum penelitian ini bersifat analisis deskriptif dengan menggunakan pendekatan deduktif Kualitatif Rasionalistik yang berfokus pada pendekatan lingkungan (behaviour approach) dan pendekatan ekonomi keruangan (spatial economic approach). Pendekatan ini dilakukan untuk melihat perubahan bentuk dan fungsi pemanfaatan ruang lahan yang ada di kawasan studi berkaitan dengan perkembangan aktivitas pemanfaatan lahan yang ada di kawasan pinggiran perkotaan. Parameternya adalah aktivitas ekonomi dan pemanfaatan ruang (Yin, 2003).

Analisis yang akan dilakukan dalam penelitian ini adalah analisis potensi dan masalah,

kondisi eksisting wilayah studi. Analisis keruangan, dengan cara mengdiskripsikan/memetakan kenampakan ruang yang diteliti menjadi bentuk bentangan area, Mengklasifikasikan kekhasan sebaran elemen pembentuk ruang yang dibahas. Pada tahap ini peneliti mengidentifikasi ke khasan sebaran obyek kajian, dengan maksud mengetahui apakah sebaran tersebut mencerminkan adanya pola tertentu atau tidak. Melakukan analisis spesifik karakter ruang ekonomi, bagaimana terjadinya, bagaimana karakternya serta dampak yang ditimbulkan. Pemetaan Pola Ruang Ekonomi, dengan melakukan supper impose peta tata guna lahan, dengan aktivitas ekonomi di wilayah studi.

\section{HASIL DAN PEMBAHASAN}

Seiring dengan perkembangan zaman dan teknologi, permintaan kebutuhan hidup manusia semakin meningkat, baik dari segi kuantitas maupun kualitas. Peningkatan kebutuhan hidup tersebut tentu akan meningkatkan aktivitas ekonomi yang dilakukan oleh masyarakat di suatu wilayah. Di daerah perkotaan, peningkatan aktivitas ekonomi akan berlangsung lebih cepat dibandingkan di daerah pedesaan karena jumlah penduduk di perkotaan lebih banyak dan gaya hidup masyarakatnya juga lebih konsumtif (Dhika,Viibi dan Brotosunaryo, 2012). Perkembangan aktivitas ekonomi pada suatu kota akan mengakibatkan 
kota tersebut menjadi semakin ramai dan terlalu padat. Akibatnya, seringkali terjadi fenomena urban sprawl yang mengakibatkan pertumbuhan fisik kota meluas hingga ke wilayah di sekitar pinggiran kota yang biasanya merupakan wilayah penyangga kota tersebut (Khadiyanto, 2005).

Sebuah kawasan umumnya memiliki sebuah potensi dan permasalahan. Potensi kawasan memunculkan sebuah kekhasan tersendiri dibandingkan dengan kawasan lainnya. Pengamatan mengenai potensi kawasan dilakukan untuk melihat faktor apa yang menjadi keunggulan dalam sebuah kawasan. Permasalahan kawasan biasanya hadir berdampingan dengan aktifitas atau kegiatan yang terjadi didalam suatu kawasan. Pentingnya mengamati permasalahan kawasan berguna dalam memberikan solusi untuk mengoptimalkan kelebihan dan potensi sebuah kawasan.

Kelurahan Temabalang berlokasi di pinggiran perkotaan Semarang, yang memiliki potensi berkembang cepat . Hal ini didorong karena keberadaan beberapa Perguruan Tinggi yang ada di kawasan Tembalang. Kondisi ini memacu tumbuhnya permukiman baru dan aktivitas ekonomi baik jasa maupn perdagangan, sehingga mempengaruhi harga lahan, yang semakin tahun semakin melambung diatas NJOP. Disamping potensi dan permasalahan terhadap pola ruang dan aktifitas ekonomi ,juga diamati dalam beberapa faktor. Faktor tersebut diantaranya geografis, infrastruktur, demografis, aktifitas ekonomi. Potensi dan permasalahan yang tersusun selanjutnya akan dilihat kaitannya dengan pola ruang ekonomi dan aktifitas ekonomi di Kelurahan Tembalang.

Tabel 1. Potensi dan Permasalahan Kelurahan Tembalang

\begin{tabular}{|c|c|c|c|}
\hline No & Faktor & Potensi & Masalah \\
\hline (1) & (2) & (3) & (4) \\
\hline 1 & $\begin{array}{l}\text { Geografis dan } \\
\text { Lokasi }\end{array}$ & $\begin{array}{l}\text { 1) Bebas Banjir karena berada di } \\
\text { daerah tinggi } \\
\text { 2) Tedapat perguruan Tinggi Negeri } \\
\text { yaitu UNDIP dan POLINES } \\
\text { Semarang } \\
\text { 3) Kawasan permukiman telah } \\
\text { berkembang } \\
\text { 4) Merupakan kawasan periurban yang } \\
\text { sedang berkembang dengan pesat. }\end{array}$ & $\begin{array}{l}\text { 1) Ekspansi lahan yang semakin tinggi } \\
\text { mengakibatkan berkurangnya ruang } \\
\text { terbuka sebagai resapan air. }\end{array}$ \\
\hline 2 & Infrastruktur & $\begin{array}{l}\text { 1) Dekat dengan jalan Tol } \\
\text { 2) Dekat dengan Jalan Nasional } \\
\text { (Semarang-DIY). } \\
\text { 3) Akses jalan telah terhubung ke } \\
\text { seluruh wilayah kelurahan } \\
\text { 4) Fasilitas umum lengkap (Bank, } \\
\text { ATM, SPBU, restoran,pendidikan } \\
\text { dan rumah sakit). } \\
\text { 5) Fasilitas sosial lengkap } \\
\text { 6) Banyak ditemukan ruang publik } \\
\text { (taman) }\end{array}$ & $\begin{array}{l}\text { 1) Sering terjadi kemacetan. } \\
\text { 2) Kebutuhan ruang meningkat namun } \\
\text { ruang yang tersedia terbatas. } \\
\text { 3) Kurangnya lahan parkir. } \\
\text { 4) Drainase kondisinya kurang optilmal } \\
\text { pemeliharaannya }\end{array}$ \\
\hline
\end{tabular}




\begin{tabular}{|c|c|c|c|}
\hline No & Faktor & Potensi & Masalah \\
\hline (1) & (2) & (3) & (4) \\
\hline & & $\begin{array}{l}\text { 7) Terdapat angkutan umum yang } \\
\text { terintegrasi }\end{array}$ & \\
\hline 3 & Demografis & $\begin{array}{l}\text { 1) Penduduk heterogen bila dilihat dari } \\
\text { asal } \\
\text { 2) Mahasiswa yang datang merupakan } \\
\text { potensi pasar. }\end{array}$ & $\begin{array}{l}\text { 1) Penduduk terus bertambah dan } \\
\text { berpindah dengan cepat menyebabkan } \\
\text { kebutuhan ruang semakin meningkat. } \\
\text { 2) Penduduk pendatang sebagai } \\
\text { mahasiswa cenderung pasif terhadap } \\
\text { lingkungan sekitar }\end{array}$ \\
\hline 4 & $\begin{array}{l}\text { Aktifitas } \\
\text { Ekonomi }\end{array}$ & $\begin{array}{l}\text { 1) Aktifitas ekonomi didominasi oleh } \\
\text { mahasiswa dan masyarakat sekitar. } \\
\text { 2) Memiliki kegiatan ekonomi yang } \\
\text { beragam seperti restoran, perbankan, } \\
\text { jasa, dll) } \\
\text { 3) Memiliki kawasan perdagangan dan } \\
\text { jasa yang lengkap merupakan } \\
\text { keunggulan dari segi perekonomian. } \\
\text { 4) Kegiatan perekonomian berlangsung } \\
24 \text { jam terutama aktifitas } \\
\text { perdagangan makanan dan } \\
\text { minuman, serta jasa fotocopi. }\end{array}$ & $\begin{array}{l}\text { 1) Menjadi kawasan dengan daya tarik } \\
\text { tinggi di bidang perdagangan dan jasa } \\
\text { membuat konsumen luar kawasan } \\
\text { ikut masuk yang sering menyebabkan } \\
\text { kemacetan. } \\
\text { 2) Ketidak seimbangan antara } \\
\text { ketersediaan ruang dengan kebutuhan } \\
\text { ruang menyebabkan kepadatan. }\end{array}$ \\
\hline
\end{tabular}

Sumber: Pengamatan Lapangan, 2020

Fungsi ruang eksisting wilayah peri urban kelurahan Tembalang didominasi oleh penggunaan lahan non pertanian yaitu perdagangan jasa, permukiman, ruang terbuka hijau serta kawasan pendidikan yaitu Universitas Diponegoro. Kelurahan Tembalang merupakan kawasan pendidikan dimana mayoritas penduduk yang tinggal adalah mahasiswa, oleh karena hal tersebut perkembangan penggunaan lahannya lebih mengarah kepada penyediaan sarana dan prasarana bagi mahasiswa seperti kostan, kafe, resto, angkringan, toko alat tulis, jasa laundry, print dan fotocopy, serta terdapat pula masjid serta rumah sakit. Kegiatan perekonomian dibidang perdagangan jasa tersebar di Kelurahan Tembalang terutama disekitaran kampus Universitas Diponegoro, dimana disekitaran kawasan tersebut terdapat berbagai aktivitas kompleks yang terjadi. Aktivitas ekonomi tersebut dipengaruhi oleh kemudahan aksesibilitas lokasi, dengan kemudahan aksesibilitas maka kegiatan perekonomian akan semakin banyak terjadi.

Fungsi ruang eksisting selain dari perekonomian terdapat pula perumahan, dimana terdapat banyak perumahan yang berada di Kelurahan Tembalang, seperti Graha Sapta Tembalang, Grand Tembalang Regency, Perumahan Permata Tembalang serta perumahan yang berada di sekitaran kampus Universitas Diponegoro yang mayoritas difungsikan sebagai Kost mahasiswa. Kost mahasiswa Universitas Diponegoro berada sangat dekat dengan gedung perkuliahannya, bahkan biasanya mahasiswa hanya tinggal berjalan beberapa meter dari kostan untuk sampai kegedung perkuliahan, selain itu fasilitas print dan fotocopy, laundry, toko alat tulis dan warung makan juga berada sangat dekat dengan kostan sehingga 
mahasiswa berada di satu tempat dengan fasilitas yang kompleks dan tidak membutuhkan banyak waktu serta tenaga untuk dapat mengaksesnya. Berikut merupakan gambaran kenampakan fungsi ruang Kelurahan Tembalang.

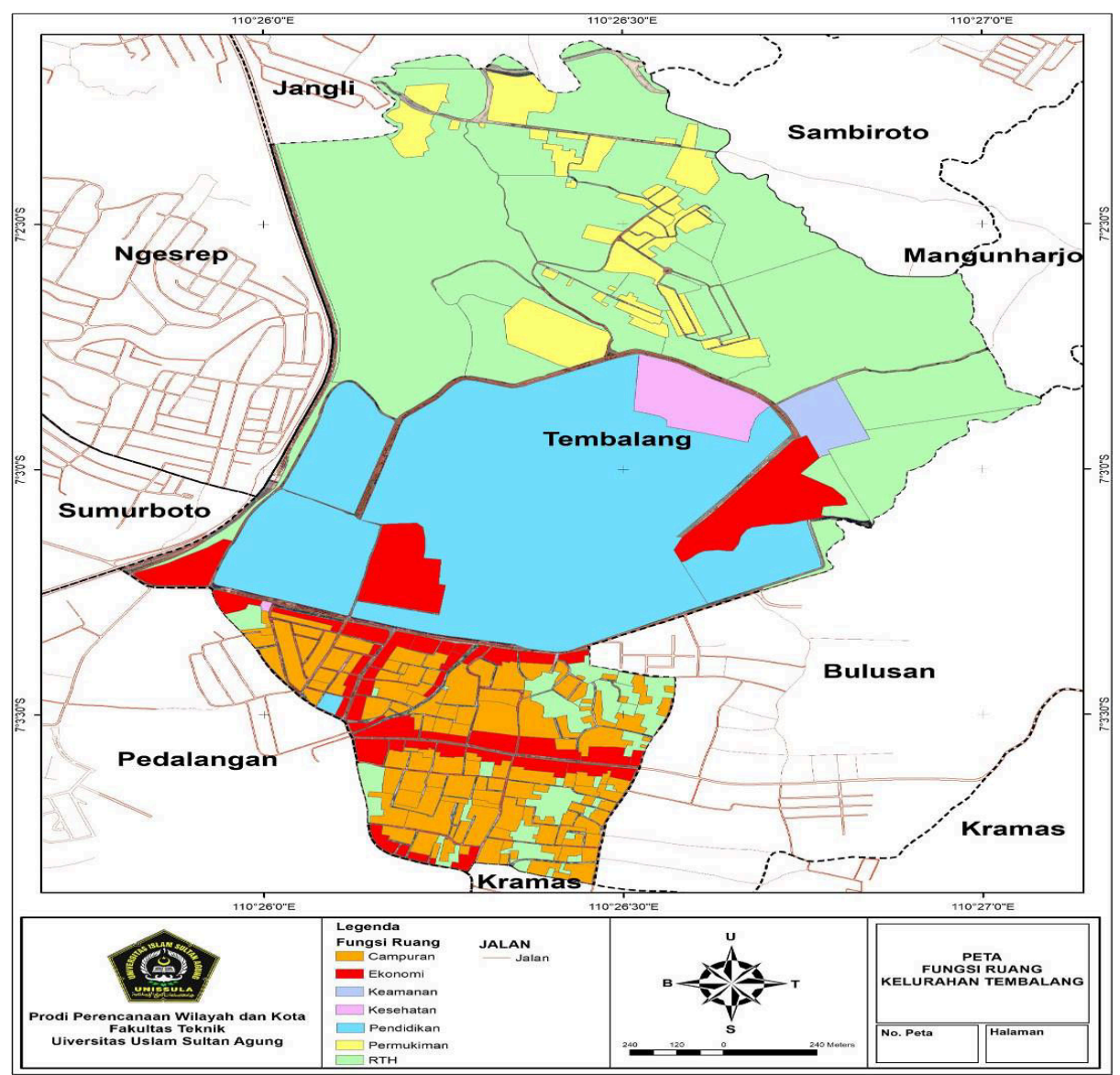

Gambar 1. Fungsi ruang Kelurahan Tembalang, Kecamatan Tembalang, Kota Semarang

Kelurahan Tembalang merupakan wilayah periurban yang sedang berkembang pesat.

Perkembangan wilayah di Kelurahan Tembalang ditunjang dengan adanya perguruan tinggi negeri yaitu Universitas Diponegoro dan Politeknik Negeri Semarang, serta Perguruan Tinggi Swasta Universitas Pandanaran. Perguruan tinggi yang ada di Kelurahan Tembalang merupakan daya tarik yangmendorong terjadinya perkembangan wilayah di kawasan periurban.

Perkembangan permukiman dan perumahan di Kelurahan Tembalang dan sekitarnya membuat aktifitas ekonomi semakin meningkat. Pada saat ini perkembangan permukiman sudah mulai dibangun vertikal karena keterbatasannya ruang. Apartment yang terdapat di Kecamatan Tembalang berjumlah 4 bangunan yaitu apartment Cordova Edupartmen, Tamansari Cendekia, Paltrow City. .Perkembangan perumahan dan permukiman menunjukan adanya keterbatasan ruang di kawasan perkotaan sehingga pengembangan tertuju pada 
kawasan periurban. Namun jika dilihat kawasan periurban khususnya Kelurahan Tembalang sudah terlihat adanya keterbatasan pengembangan ruang secara horizontal. Perkembangan ini tentunya memiliki pengaruh terhadap perekonomian.

Kelurahan Tembalang memiliki efek luas dalam kegiatan ekonomi ke kelurahan sekitar sehingga perkembangan periurban semakin luas. Jenis perekonomian yang berkembang di Kelurahan Tembalang dan sekitarnya berupa perdagangan dan jasa. Kegiatan perdagangan meliputi restoran, elektronik, alat tulis. Bentuk jasa yang berkembang meliputijasa fotocopy, jasa pemotretan, jasa perbankan, jasa konveksi, jasa persewaan property, jasa perhotelan, dan jasa penyewaan.

Kelurahan Tembalang memiliki Pola Ruang Ekonomi yang berkembang di sepanjang jalan utama. Kegiatan perekonomian yang mengikuti jalur jalan utama ini mementuk pola jaringan. Pola ruang ekonomi ini juga masih terlihat pada kawasan sekitarnya. pola perekonomian seperti ini memiliki keunggulan dan kekurangan dalam kegiatannya. Berikut peta pola ruang ekonomi Kawasan Tembalang.

Keunggulan pola ruang ekonomi yang mengikuti jalan yaitu strategis, pengoptimalan ruang privat rumah, ekonomis karena tidak membuka lahan khusus. Sedangkan kekurangannya adalah sepanjang jalan terjadi kemacetan, bertambahnya beban fungsi jalan, harga lahan/sewa menjadi tinggi, munculnya PKL yang tidak berizin, munculnya juragan lahan yang menariki pajak/ biaya keamanan tidak berijin. Berikut merupakan identifikasi pola ruang ekonomi kelurahan tembalang.

Pengembangan wilayah pinggiran kota secara terpadu terkait erat dengan kota utama. Mengingat salah satu penyebab kurang berkembangnya ekonomi lokal, disebabkan sebagian besar penduduk perumahan bekerja dan bersekolah di kota Semarang, sehingga mereka lebih sering belanja ke kota. Pengembangan sarana dan prasarana ekonomi di daerah pinggiran kota dengan disertai peningkatan daya saing, khususnya dalam efektifitas harga diharapkan akan berfungsi sebagai penghambat laju belanja ke kota (Aryani, 2010).

Pola kegiatan ekonomi secara tidak langsung mengarah pada mata pencaharian masyarakat yang tinggal, dimana mata pencaharian sendiri adalah kegiatan dalam memenuhi kebutuhan hidup baik kebutuhan hidup individu maupun kebutuhan hidup keluarga. Dalam memenuhi kebutuhan hidup sehari-hari maka seseorang akan mencari pekerjaan sesuai dengan kemampuan yang dimiliki. Mata pencaharian dapat diklasifikasikan berdasarkan dua golongan yaitu tempat dan jenis pekerjaan, yang termasuk dalam tempat adalah perekjaan yang dilakukan di daerah desa ataupun di kota, sedangkan yang termasuk dalam jenis pekerjaan adalah dibidang pertanian atau non pertanian. 


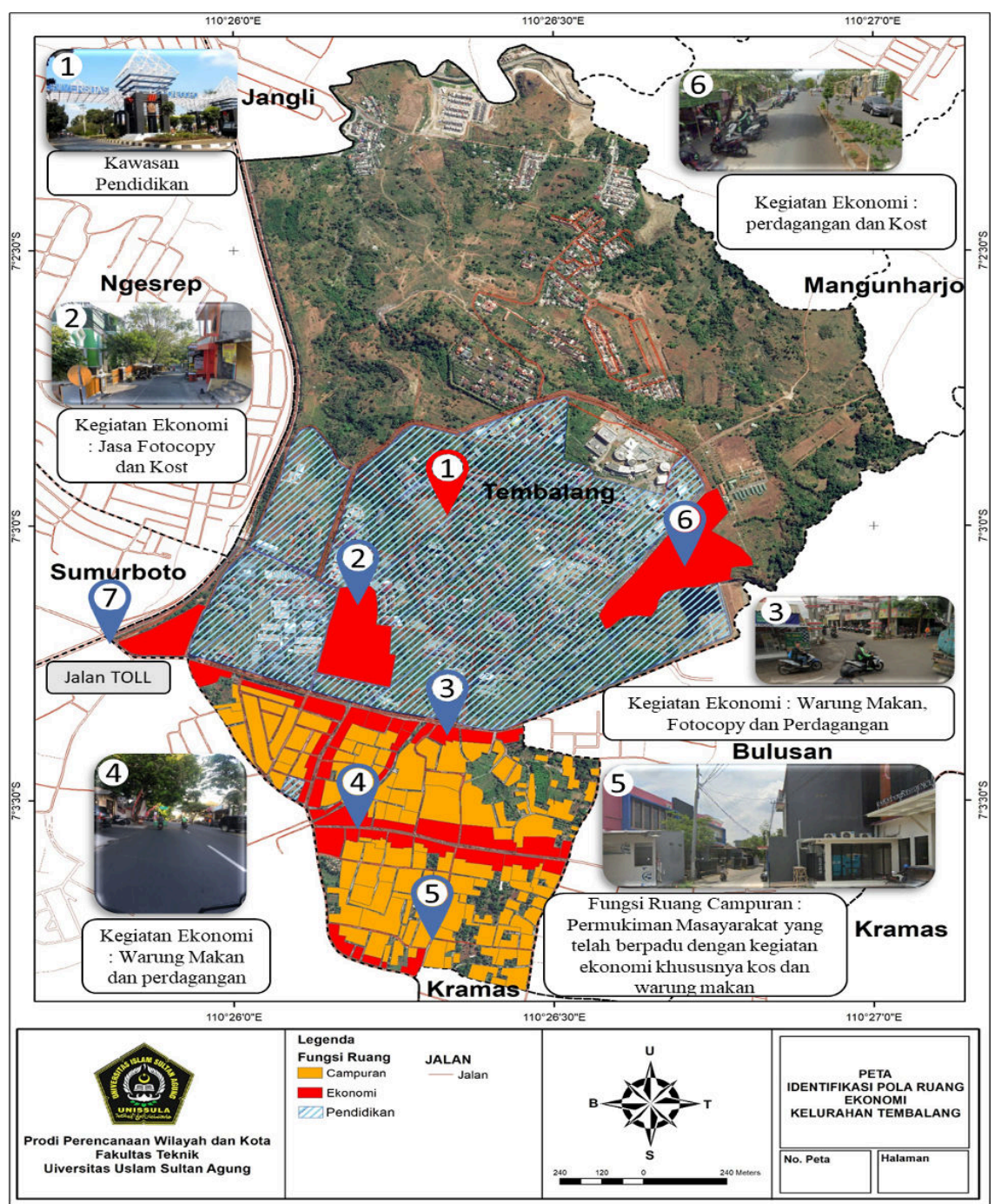

Gambar 2. Peta Pola Ruang Ekonomi Kawasan Tembalang

Mata pencaharian mayoritas di Kelurahan Tembalang adalah dibidang non pertanian seperti perdagangan jasa. Kelurahan Tembalang yang merupakan kawasan pendidikan semakin pesat berkembang terutama dalam sektor perdagangan jasa, dimana sektor tersebut berkembang pesat karena untuk memenuhi kebutuhan masyarakat yang tinggal. Kelurahan Tembalang didominasi oleh imigran yang datang untuk menuntut pendidikan di Universitas Diponegoro, dengan bertambahnya penduduk yang datang maka banyak lahan terbuka menjadi lahan terbangun guna memenuhi kebutuhan masyarakatnya.

Konstelasi Kelurahan Tembalang dengan kawasan disekitarnya dalam aktivitas ekonomi dapat dilihat dari keluar masuknya barang perekonomian, dimana untuk memenuhi kebutuhan sehari-hari masyarakat Kelurahan Tembalang mengambil barang dari pasar-pasar yang paling dekat atau berada di sekitar kawasan. Pasar yang biasanya memasok barang untuk kebutuhan masyarakat Kelurahan Tembalang adalah pasar Rasamala dan pasar Damar 
Banyumanik. Jadi konstelasi atau hubungan yang paling banyak terjadi dengan Kelurahan Tembalang adalah Kecamatan Banyumanik karena banyak barang yang beredar di Kelurahan Tembalang adalah berasal dari Kecamatan Banyumanik, selain pasar tradisional terdapat pula pasar moderan yaitu Transmart dan ADA Setia Budi, yang selalu dikunjungi masyarakat salah satunya adalah masyarakat yang berasal dari Kelurahan Tembalang untuk memenuhi kebutuhan hidup sehari-hari, mulai dari kebutuhan pokok dan kebutuhan lainnya sudah tersedia di pasar modern tersebut.Selain Kecamatan Banyumanik masyarakat Kelurahan Tembalang melakukan aktivitas ekonomi hanya di dalam Kelurahan itu sendiri karena mayoritas penduduk yang tinggal adalah perantau atau penduduk tidak tetap jadi mereka lebih banyak melakukan aktivitas ekonomi di Superindo atau di toko yang berada didalam Kelurahan Tembalang.

Aktivitas ekonomi di Kelurahan Tembalang, didukung ketersediaan sarana yang ada di wilayah tersebut ataupun layanan wilayah kecamatan. Pergerakan masyarakat dalam memenuhi kebutuhan ekonomi tidak terbatas pada layanan kelurahan, melainkan terkait dengan sarana disekitar wilayahnya.

Kelurahan Tembalang tidak memiliki sarana pasar dari tahun 2016 sampai 2019, untuk toko dari tahun 2016 sampai 2018 tidak memiliki perubahan yaitu hanya memiliki 8 toko, namun pada tahun 2019 mengalami kenaikan yang cukup signifikan yaitu menjadi 24 toko, untuk sarana kios dari tahun 2016 sampai pada 2018 memiliki kios dengan jumlah 18 unti kios, sedangkan ditahun 2019 tidak ada kios. Sarana warung pada tahun 2016-2018 memiliki jumlah yang sama yaitu 25 unit warung sedangkan pada tahun 2019 memiliki kelonjakan yang cukup banyak yaitu menjadi 99 unit warung.

Pertumbuhan jumlah penduduk di perkotaan yang begitu pesat menyebabkan kebutuhan lahan semakin tinggi. Kebutuhan yang meningkat akan mengakibatkan nilai lahan juga semakin tinggi. Nilai lahan merupakan penilaian atas lahan secara ekonomi (Wahyuningsih, 2008).

Kondisi perkembangan aktivitas ekonomi di kawasan Kelurahan tembalang, mempengaruhi peningkatan harga lahan. Menurut hasil wawancara responden yang berada di wilayah studi dibedakan pada koridor jalur utama dan sample responden di dalam perkampungan sebagai berikut :

"saya sewa tempat usaha salon disini Jl Sirajudin sejak tahun 2003 luas $4 \times 7$ m setahun Rp 7 juta, sekarang harga sewa disini setahun Rp 15 juta” (Responden LD, 10 oktober 2020). 
Jurnal Planologi Vol. 18 No. 2, Oktober 2021 Available : http://jurnal.unissula.ac.id/index.php/psa

Narasumber lain yang rumahnya koridor jalan utama Banjarsari menyatakan :

“ harga lahan disini luar biasa mas, sekarang per meter Rp 10 juta, PBB saya bayar tahun 2020 sekitar Rp 4,2 juta, dengan luas sekitar 300meter2. NJOP nya per meter 1,4 juta. “(Responden S, 12 Oktober 2020)

Dilihat dari aktivitas jasa kost, dalah satu narasumber menyatakan :

"saat ini sewa kost per kamar dengan fasilitas standar tempat tidur, meja belajar dan almari, kamar mandi diluar harganya Rp 500 ribu/bulan. Sedangkan kalau kamar mandi dalam 600 ribu /bulan. Kalau ada TV dan Ac beda lagi, sebulan bisa Rp 1.2 juta" (Responden AS, 12 Oktober 2020).

Lain lagi untuk yang usaha PKL, menurut narasumber menyatakan :

"saya jualan buryam ini siang hari saja mbak, sampai habis kira-kira dhuhur, sewa tempat di teras ini sehari 25 ribu, luasnya ya hanya segini kira2 $6 m \times 3 m$ fasilitasnya hanya dapat air bersih, tenda dan alat pasang sendiri. Kalau sore yang jualan ganti orang, ditarik sewa yang sama dengan tambahan fasilitas listrik. Jadi kami kerjasama dengan penyewa yang malam dalam menyiapkan tenda dan meja kursi,dll (Responden S, 10 Oktober 2020).

Di Kawasan Tembalang saat ini terdapat bangunan apartemen 30 lantai, yang belum sepenuhnya dihuni. Namun penjualan hostelnnya sudah $80 \%$ sold. Dari wawancara dengan marketing Potrown menyatakan sebagai berikut :

“ harga apartement disini ukuran $3 \times 5$, tanpa fasilitas furnitur Rp 425 juta.DP minmal $10 \%$, sisanya diangsur bisa sampai 15 tahun” (Responden I,10 Oktober 2020)

Menurut Catanase 1986, Teori Ricardo merujuk pada sewa lahan (land rent) yang dipengaruhi oleh tingkat kesuburan tanah dan mengabaikan faktor lokasi dari pusat kota. Von Thunen menyatakan bahwa pola penggunaan lahan sangat ditentukan oleh biaya transportasi yang dikaitkan dengan jarak dan sifat barang dagangan khususnya hasil pertanian. Von Thunen mengkondisikan ada empat hal yang harus dipenuhi, yaitu : (1) isolated state; (2) uniform plain; (3) "transportation costs" berbanding lurus dengan jarak; dan (4) maximise profits. Kalau menurut teori tersebut,dalam penelitian ini terjdi penyimpangan. Karena lokasi studi yang berada di kawasan pinggiran perkotaan Semarang, dengan jarak sekitar $15 \mathrm{~km}$ dari pusat kota Semarang, dahulunya adalah kawasan pertanian.. Perkembangan Kawasan Tembalang yang cukup pesat, dimana telah terjadi alih fungsi lahan pertanian menjadi kawasan permukiman, perdagangan dan jasa telah terjadi peningkatan nilai lahan yang sangat tinggi . 
Jurnal Planologi Vol. 18 No. 2, Oktober 2021

Available : http://jurnal.unissula.ac.id/index.php/psa

\section{KESIMPULAN DAN REKOMENDASI}

Kelurahan Tembalang memiliki fungsi sebagai kawasan pendidikan dan kawasan permukiman. Kegiatan ekonomi di kawasan ini berdampak ke kelurahan sekitar sehingga perkembangan periurban semakin luas. Jenis perekonomian yang berkembang di Kelurahan Tembalang dan sekitarnya berupa perdagangan dan jasa. Kegiatan perdagangan meliputi restoran, elektronik, alat tulis. Bentuk jasa yang berkembang meliputijasa fotocopy, jasa pemotretan, jasa perbankan, jasa konveksi, jasa persewaan property, jasa perhotelan, dan jasa penyewaan.

Kelurahan Tembalang memiliki Pola Ruang Ekonomi yang berkembang di sepanjang jalan utama. Kegiatan perekonomian yang mengikuti jalur jalan utama ini membentuk pola jaringan. Pola ruang ekonomi ini juga masih terlihat pada kawasan sekitarnya. pola perekonomian seperti ini memiliki keunggulan dan kekurangan dalam kegiatannya

Pola ruang ekonomi yang berkembang pada koridor jalan utama, memiliki nilai jual lahan yang tinggi. Semakin tahun mengalami kenaikan harga lahan baik menurut NJOP, harga sewa lahan maupun harga jual lahan.

Dari hasil penelitian ini peneliti memberikan rekomendasi pada Pemerintah Kota Semarang sebagai berikut :

1. Perlunya pengendalian penataan ruang khususnya di Kelurahan Tembalang, sesuai peruntukannya, dan tetap mengalokasikan lahan terbuka sebagai fungsi resapan air.

2. Pembangunan infrastruktur, khususnya jaringan drainase menjadi prioritas utama dan perlu pemeliharaan dengan baik, agar tidak terjadi bencana banjir.

3. Penertiban perijinan untuk bangunan baru, baik permukiman, perdagangan dan jasa. Rekomendasi untuk masyarakat di lingkup kawasan Kelurahan Tembalang :

1. Mentaati peraturan Pemerintah Kota dalam mendirikan bangunan.

2. Menjaga dan memelihara jaringan infrastruktur, terutama jaringan drainase di lingkup permukiman.

Rekomendasi untuk akademisi :

Perlu ada kajian lebih lanjut terhadap penyimpangan bangunan di Kelurahan Tembalang, yang tidak sesuai dengan peruntukkannya.

\section{DAFTAR PUSTAKA}

Khadiyanto, P. (2005). Tata ruang berbasis pada kesesuaian lahan. Semarang: Universitas Diponegoro.

Yin, R, K. (2003). Case Study Research, Design and Methods. Third edition. California: Sage Publications. 
Jurnal Planologi Vol. 18 No. 2, Oktober 2021

Available : http://jurnal.unissula.ac.id/index.php/psa

Yuliani. (2016). Pengembangan wilayah di Kawasan pinggiran Perkotaan. Multipres. Semarang

Yunus, H. S. (2008). Dinamika wilayah peri-urban: determinan masa depan kota. Pustaka Pelajar.

Yunus, H. S. (2005). Struktur Tata Ruang Kota. Penerbit Pustaka Pelajar, Yogyakarta.

Zahnd, Markus. (2003). Perancangan Kota Secara Terpadu. Yogyakarta: Kanisius.

Wahyuningsih, M. (2008). Pola dan Faktor Penentu Nilai Lahan Perkotaan di Kota Surakarta (Doctoral dissertation, Universitas Diponegoro).

Indrayati, A. (2010). Peranan Wanita Dalam Pemberdayaan Ekonomi Lokal (Studi Kasus Tentang Pola Ruang Belanja Wanita di Daerah Pinggiran Kota Semarang). Jurnal Geografi: Media Informasi Pengembangan dan Profesi Kegeografian, 7(2).

Nur, Arozan (2018) Analisis Struktur Ruang, Pola Ruang, dan Kawasan Strategis Kabupaten Tangerang. https://medium.com/arozan22

Nilayanti, V. D., \& Brotosunaryo, P. M. (2012). Pengaruh Perkembangan Aktivitas Ekonomi Terhadap Struktur Ruang Kota Di SWP III Kabupaten Gresik. Teknik PWK (Perencanaan Wilayah Kota), 1(1), 76-86. 